DOI: $10.30525 / 978-9934-588-61-7-29$

Shymanska O. A.

Master in Finance

National University of Kyiv-Mohyla Academy

Primierova O. K.

Ph. D. in Economics, Associate Professor, Department of Finance

National University of Kyiv-Mohyla Academy

\title{
INTERNATIONAL MIGRATION AND THE EU'S LABOUR MARKETS: TO PROTECT OR NOT PROTECT?
}

\begin{abstract}
Summary
International labour migration has been a highly controversial issue that challenges European governments for a long lime. Currently, there is not any consolidated position among the EU's member states towards immigrant workforce. Thus, every country decides on its own whether to open an access for foreigners to local labour markets or not. In this article we endeavour to explore benefits and drawbacks of labour immigrants' inflows for the host countries. Besides, this study aims to research how immigrant workforce affects local labour markets, economic growth, and distribution of welfare. More specifically we will focus on impact of complementing and competing immigrants' influx on host economies in terms of employment and economic growth
\end{abstract}

\section{Introduction}

Migration has been a widely discussed topic in the EU over the last decade but still researches have not reached the consensus regarding whether or not to allow immigration flows from the third countries. In fact, the EU has always attracted a lot of immigrants, both legal and illegal, who sought a better life elsewhere in Western Europe. Though, migration became a matter of top concern since thousands of refugees crossed the EU border in 2014. This unprecedented flux of people that needed considerable expenditure from public budgets of receiving countries raised a wide range of questions for both researches and policymakers. Although a number of asylum seekers tend to decline during last couple of years, a labour migration continues to grow both on permanent and temporary basis. Subsequently, in 2019, the European Parliamentary Research Service has concluded that migration management «will remain high on the European agenda» [1] so the study of international migration and its impact on labour markets of receiving countries and their economic growth is pertinent now as never before.

The position of each country towards migration largely depends on the structure of economy, the age structure of population, political parties at power and other factors that condition the decision of policymakers to protect internal labour market from foreign workers or, on the contrary, to create favourable conditions for specialists from other countries. Currently we can 
see example of both policies in the EU. For example, Poland and the Czech Republic issue residence permits under a simplified procedure for the Ukrainian workers and allow students to stay in the country after the graduation to seek for a job without any quota system. On the other hand, France and Belgium tend to protect local labour market from foreigners, putting a lot of barriers to employments of immigrants.

This study aims to research how immigrant workforce affects local labour markets, economic growth, and distribution of welfare. More specifically we will focus on impact of complementing and competing immigrants' influx on host economies in terms of employment and economic growth.

\section{Part 1. Overview of migration processes in the EU}

Migration has always been a matter of concern in the EU. Firstly, there have been lots of illegal immigrants arriving to do a non-qualified job. These people arrived from emerging countries with high unemployment rate and considerable inequity, as the former Soviet republics, the Balkan countries, exhausted by ethnical conflicts, or countries of North Africa. Secondly, refugees have been arriving from Middle East since the Gulf war. Of course, there are also legal immigrants, who come to the European countries according to established procedures, but, nevertheless, position of governments of the European countries towards them is ambivalent. Finally, category of immigrants includes also the European citizens who have preferred to change their previous residence. Eurostat points out that 22.3 million people (4.4\%) of the 512.4 million people living in the EU as of January 01, 2018 were non-EU citizens In particular, the highest concentration of non-EU nationals was recorded in Germany $(9.7 \mathrm{mln})$, Italy $(5.1 \mathrm{mln})$, France $(4.7 \mathrm{mln})$, and Spain $(4.6 \mathrm{mln})$ [12].

OECD states that Germany remains the first most frequently chosen country for single destination for immigration since 2015 in the European area. Temporary labour migration, which includes seasonal workers, is mostly concentrated in Poland due to a direct border with Ukraine, an emerging democracy in the Eastern Europe [18] (OECD, 2019).

The yearly influx of long-term immigrants to the EU (27) exceeds $2.5 \mathrm{mln}$ people since 2007. The Figure 1 shows a number of long-term immigrants arriving to the EU between 2007 and 2018. It can be seen that the amount of people arriving into the EU peaked in 2015 and amounted to $4.1 \mathrm{mln}$. After a brief decline to $3.6 \mathrm{mln}$ in 2016, a number of new arrivals grew gradually in 2017, and reached a point of $3.9 \mathrm{mln}$ in 2018.

Despite considerable efforts of the Commission to encourage member states to share responsibility over refugees and elaborate appropriate policies on legal migration, immigrants still are not evenly allocated over the territory of the EU. The Table 1 (Annex A) represents an influx of immigrants as a share of population in the EU's member states. Figure 1 draws on the data of OECD statistics, which refers to «immigrants who are granted a residence permit, which is indefinitely renewable, although the renewability is sometimes subject to conditions, such as holding of a job». Data on Croatia, 
Cyprus, Malta, and Romania is not available at the OECD database. As you can see from the Table 1, in 2017, immigrants accounted for the most notable share in population in Luxembourg (3.7\%), Sweden (1.3\%), Slovenia (1.3\%), Austria (1.1\%), and Germany (1.1\%).

It should be mentioned, though, that Luxembourg has hosted mostly immigrants from the other EU's member state (94\%), the same tendency demonstrated Slovakia (79 \%) and Romania (69 \%). On the contrary, immigrants arriving to Italy belong mostly to non-EU nationals (78.2 \%), as well as those arriving to Slovenia (72.4\%), Sweden (69.1\%) and Spain $(71.8 \%)[12]$.

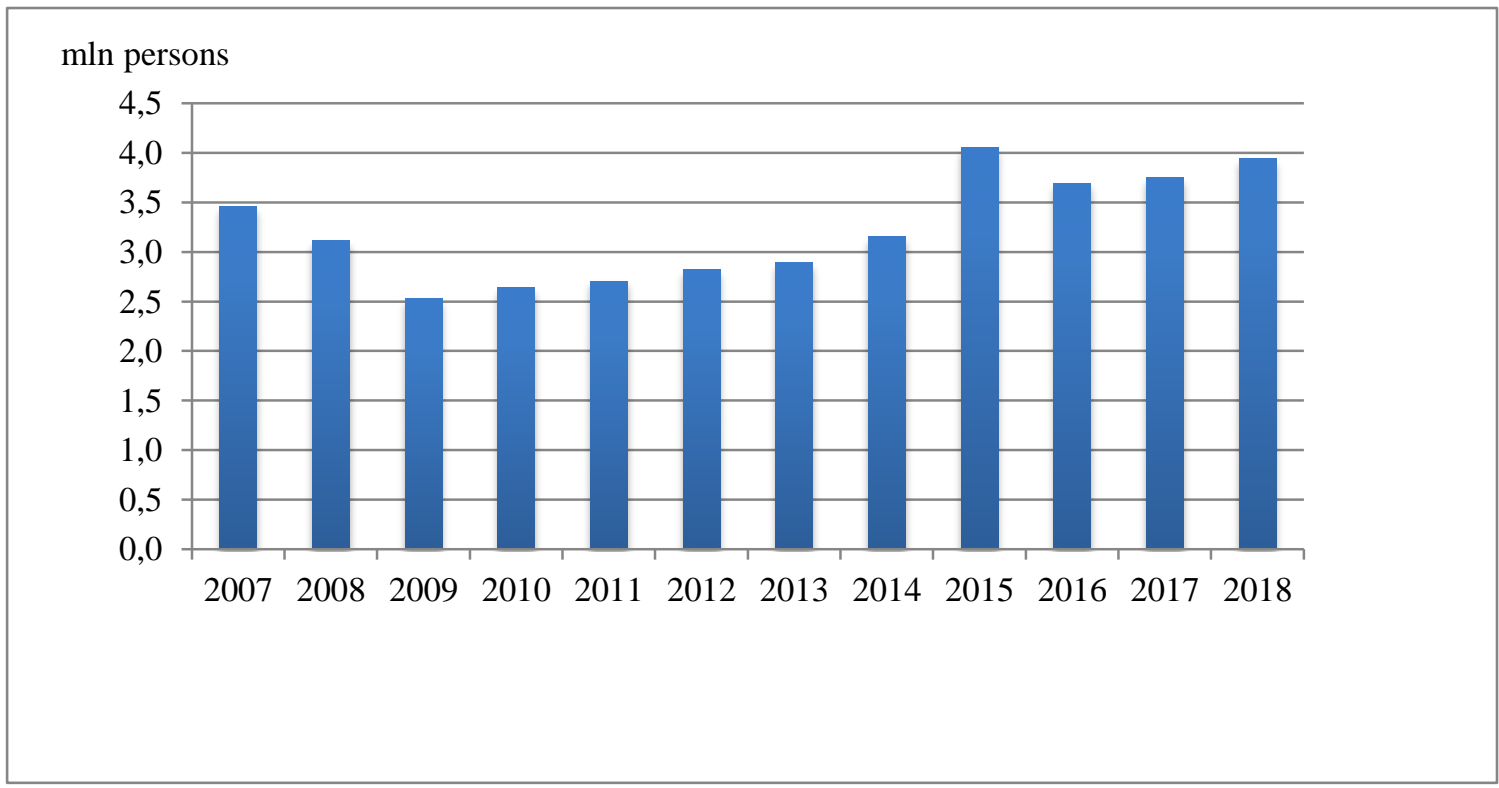

Figure 1. Total number of long-term immigrants arriving into the EU ( 27 countries)

Source: elaborated using Eurostat data

Though, we have to distinguish different types of immigrants that arrive in the EU. Firstly, there are several classifications of immigrants on the basis of country of birth, nationality, length of stay. Furthermore, analysing statistical databases, as Eurostat and OECD, we can see that immigrants are also classified by education, purpose (labour immigrants or asylum seekers), age, and sex. The definition of immigrant is a quite debatable topic, because dictionaries generally distinguish terms «immigrant» from «migrant». While the former usually refers to people who have settled in a country different of one where they were born, the latter makes reference to temporary residents. At the same time, both these terms are regarded as interchangeable in public debate and in the scholarship. Furthermore, from the legal perspective there is not any clear definition of migrant/immigrant, instead there are those who are subjects of immigration control and those who are not [5]. In this research we will use classifications on the basis of purpose, in particular, we will analyse labour immigrants. 
Economics of immigration distinguished two main types of immigrant workers: competing and complementing. Competing workers are those who can be substitutes for local ones, while complementing workers can increase job opportunities. Complementing workers do not compete with the nativeborns for the same positions, but, on the contrary, increase job opportunities [20].

There is no doubt that legal labour migration is an important tool to deal with labour market shortages. For example, in Poland, in the period of 2013-2018, contribution of labour force of the Ukrainian origin amount to 13\% GDP grow. In addition, the Ukrainian workers increased growth in the effective labour supply in Poland by $0.8 \%$ per year. Indeed, the overwhelming majority of Ukrainians arrive to Poland for economic reasons, and Polish Central Bank considers a strong labour demand the main factor that pushes Ukrainians to immigration. Though, this is mostly about a short-term job that not require particular qualification [19, p. 7].

Talking about high-skilled immigrants, we have to mention a decisive role of the EU policies towards attraction of non-EU nationals who can contribute greatly economic growth due to specific qualifications and experienced imported by them into the host countries. The EU Blue Card introduced in 2009 is a work permit that can be issued for highly qualified employees with proven professional background. There are also other incentives that may differ from country to country, ranging from non-quota procedures for job application to special packages of incentives included in job proposal.

Though, it should be admitted that immigrant workers will notably boost economic growth in case they legally arrived to the host country. Otherwise, considerable negative effects will take place. Although we cannot deny that even illegal workers contribute to GDP, as they are involved in production chains and create added value, government experiences tax revenue losses. Moreover, illegal workers have no social and health security, so government becomes responsible for cost of medical care and hospital treatment. For example, in Italy, irregular immigrants and their children can obtain STP code to access all medical services at the expense of public budget, not to say that taxpayers actually will pay for that [9, p. 8]. After all, illegal immigrants usually work for an underground economy at below-minimum wages, consequently legal workers become less competitive compared to illegal ones [7, p. 329].

Generally, impact of migration on the host country's economy depends on a range of factors, as age, education, professional background, ability to integrate into the local communities, knowledge of languages. According to OECD, migrants account for $70 \%$ of the increase in the workforce in the EU since 2004. In fast growing economies, they can help employers to handle labour shortages; especially this is about blue-collar positions. Though, public policies play crucial role in the impact of immigration on the host country's economic growth and human capital development in receiving countries [10].

The EU assumes a responsibility for managing migration flows arriving through Eastern, Central, and Western Mediterranean routes. In 2016, a 
Resolution of the European Parliament on the situation in the Mediterranean and the need for a holistic EU approach to migration was adopted. The Resolution points out that working-age population in the EU is likely to decline by 7.5 million by 2020 . At the same time, current European approach to labour migration is fragmented, compounded by numerous regulations, which actually disables high-skilled third-country nationals to obtaining recognition of their foreign qualifications and apply for a job, while a lot of sectors in the EU labour marker experience shortages [11].

Despite immigration labour regulation has many shortcomings, a wide range of rules and frameworks was established at supranational level to facilitate legal migration, which encompasses asylum seekers, highly skilled workers, students and researchers, seasonal workers, and family reunification. In addition, the EU has elaborated procedures on refugee's reallocation and integration of third-countries nationals into the European community. Though, each member-state has a certain level of discretion on quotas, legal procedures and segments of labour market the immigrants have an access to.

\section{Part 2. Competing workers' influx}

Economic theory argues in favour of migration and claims its positive impact on economic grows. On the global level, some studies argue that if one-half of the population living in poor regions migrated to advanced industrial countries, global GDP would increase by 20 to $60 \%$ [2, p. 13; 8]. In fact, Oxford Martin School's report (2018) shows that German real GDP would have been 155 bln EUR lower if migration had been frozen in 1990 [13]. Social welfare obtained due to immigrants is called «immigration surplus». This surplus grows as more immigrant labour force is present in the market and as more wages falls for this reason.

Though, the effects are different in the short and long run, and highly depend on complementarity of workers. The first type of workers we will describe in this paper is competing type, sometimes also called substitute. These are workers who compete for the same jobs on the same market. They are almost equally skilled, so the outcome of their labour activities will not change if we substitute one worker with another one. In this study we will discuss impact of competing migration as if all workers were absolutely equal, we should admit that in reality a perfect substitution of one immigrant worker with local one is a rare case.

Some studies show that there is an immigration wage gap exists between locals and immigrants with seemingly the same characteristics. Actually, working at the same position, immigrants do not do the strictly the same job as natives do, so they earn less. To some extent it can be explained also by the fact that quality of education of immigrants de facto does not match the local one, so the job autonomy of immigrants is lower. According to recent studies, going one level up on job autonomy scale increases the wage by about $13 \%$ [3, p. 19].

So, immigrants are less competitive than the native-borns due to lack of good knowledge of language and local culture. Therefore, in our simplified 
analysis we will neglect these differences. In order to show effects of immigration on labour marker of the host country, we will use DemandSupply model. Firstly, we will describe short-run effects of competing immigrants' influx. The Oxford Martin School's report states that migration can have damaging implications on a localized and short-term basis [13]. Figure 2 demonstrates how influx of competing immigrants affects wages in the short run. Here we place wages per hour as abscissa and quantity of workers on the market as ordinate. Initial point of equilibrium corresponds to 15 EUR per hour and 300 workers (supposedly in this simplified model).

After the influx of competing immigrants (now there are 100 workers more), labour supply on the market of receiving country increased, so the supply curve moves to the right. Consequently, new point of equilibrium moves to the right and down, which corresponds to lower wages. So, influx of 100 immigrants in the short run caused reduction of hourly wage from 15 to 10 EUR.

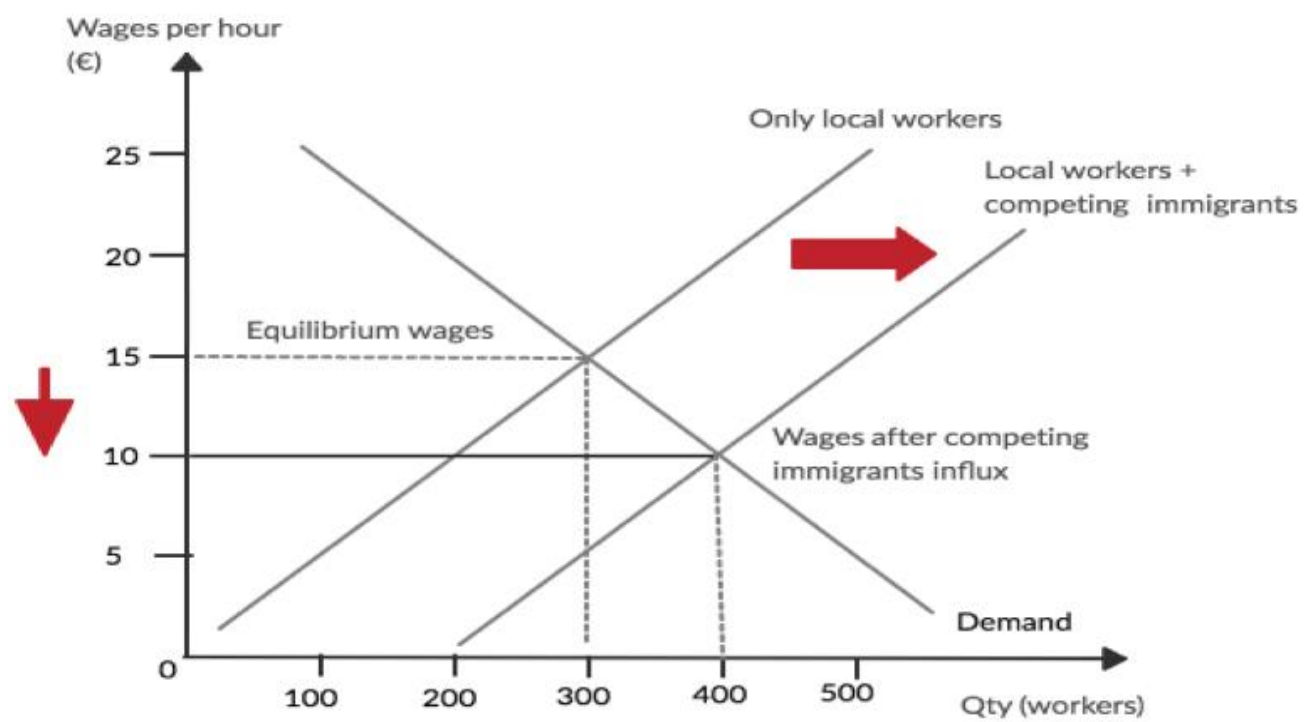

Figure 2. How increase in Supply of workers impacts wages in the short run?

In the long run, effects are different, because apart from labour, we can change all factor of production, especially capital. Taking into account the influx of working force, companies are likely to decide to expend production. So, they will hire more workers, and consequently the demand curve will move to the right. Figure 3 represents effects of competing immigrants' influx in the long run. 


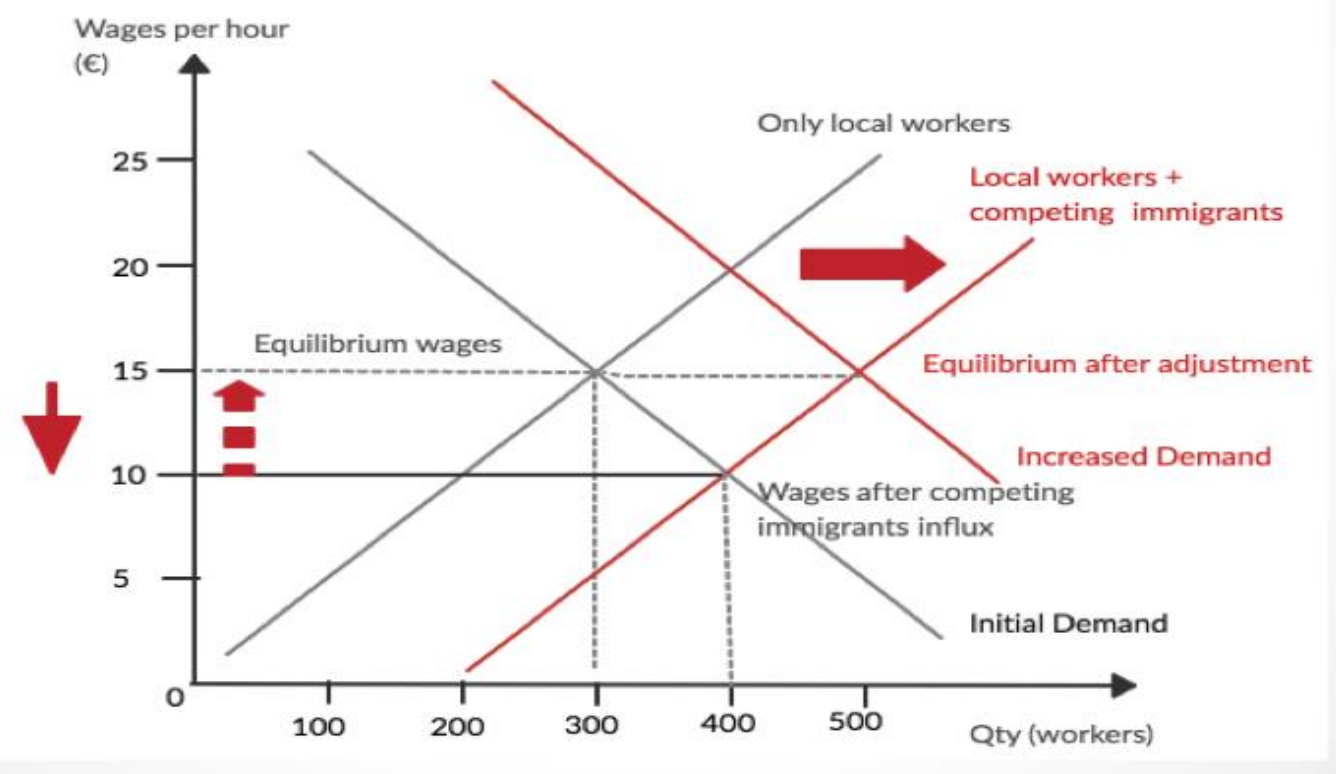

Figure 3. Long run adjustment in case of competing, and immigrants' influx

As you can see from Figure 3, companies hire more people in the long run, so point of equilibrium adjusts. In this very simplified model, wages per hour returns to its previous level, and other 100 local workers are hired (we consider these additional workers local ones as number of immigrants in our model is fixed). Finally, in the long run ever agency betters off: more workers have a job, companies produce more and obtain more income, and government receives more taxes, so public welfare grows.

It should be added that even in the short run negative effect of immigration on wages of locals is not that unequivocal. As we have said before, in real life immigrants hardly can perfectly substitute native-borns. Therefore, empirical findings from Germany evidence that $1 \%$ increase of labour force through influx of immigrants increase the unemployment rate of immigrants by $1.16 \%$ and reduces their wages by $1.09 \%$, while the wages of the native-born tend to increase and their unemployment tend to fall. Migrants can improve the adjustment capacity of regional differences by taking jobs in sectors where local people are unwilling to work [15, p. 32]. International migration could compensate for low mobility within the EU, can support a better utilization of available skills by contributing to improving the skill-mix and by increasing the overall improvement human capital

\section{Part 3. Complementing workers' influx}

Complementing workers are those who do not compete for jobs with locals, but complement them in fast growing industries and service sectors. These workers can be either high skilled and low skilled, white collar or blue collar, because complementarity depends on current shortages of every particular labour market. For example, if there are high-skilled engineers that have 
developed an innovative highway project, workers to bring this project to life will be required and so on.

High-skilled workers can also be complementary to each other. Such cooperation between local and immigrant high-skilled workers pushes innovation, increases productivity and stimulated economic growth. In addition, these workers are not prone to accept lower salaries. Generally, these workers come from emerging economies. This phenomenon is called brain drain, as highly educated people move from native countries and to industrialised ones, hindering growth of their countries of origin [7, p. 329].

Globalization processes which resulted in human recourses outflow from the European countries to China and Arab Emirates caused skill shortages in many EU countries. Demographic challenges and innovation pressures push the EU to attract highly qualified labour from the third countries [6, p. 51].

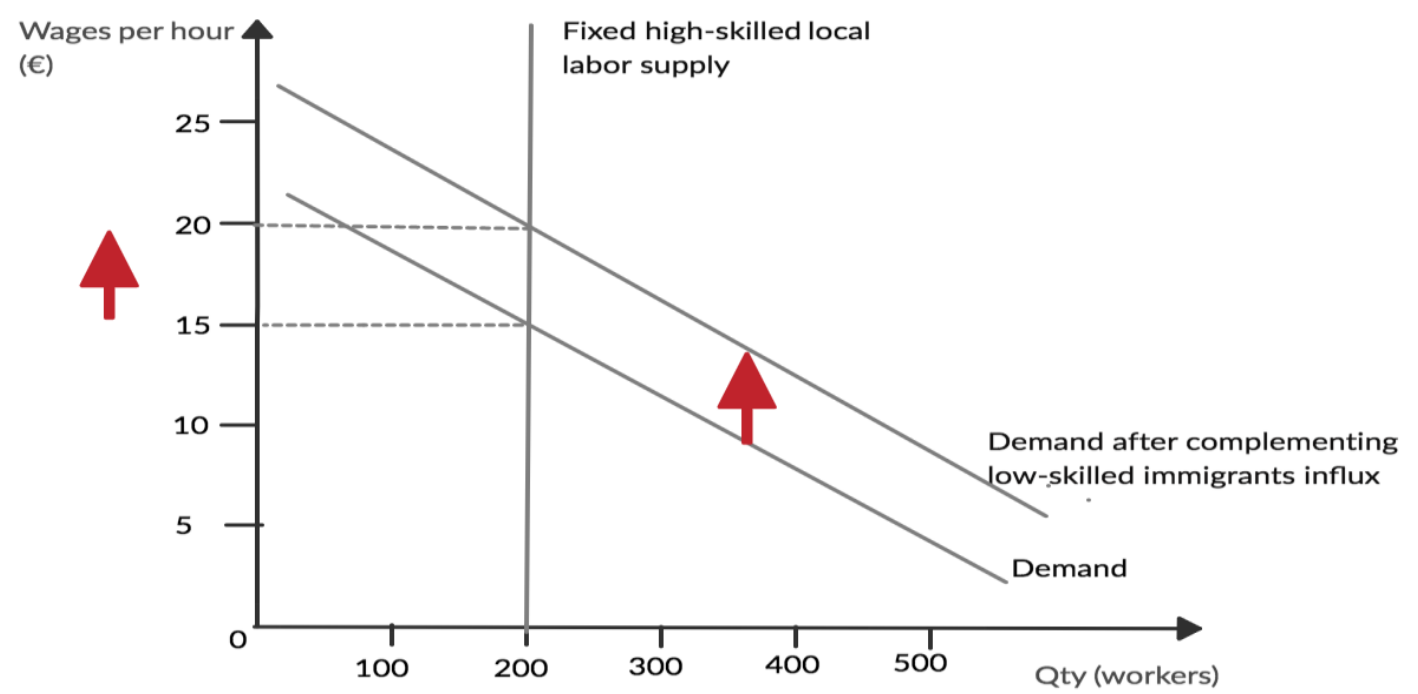

\section{Figure 4. Influx of complementing low-skilled workers and its impact on high-skilled local labour market}

Though, not only high-skilled workers can complement each other. Low skilled immigrants can successfully complement capital and high-skill labour of natives, increasing their productivity. So, we use Figure 4 to illustrate how influx of complementing low-skilled workers push for wages increase on high-skilled local labour market.

In fact, complementarity of workers usually can be regulated by public policies, which can support certain directions of education within country and facilitate immigrants' inflows with regard to their educational background and ability to match local employment demand. Recent studies show that complementarity of arriving immigrants highly depends on structure of economy. For example, the latest Talent Shortage Survey, conducted by ManpowerGroup, evidences that of the more than 42000 employers surveyed, $40 \%$ are experiencing difficulties filling vacancies. This is the highest level since 2007. In Poland, this amounts to 45\%, moreover, 
employers in Romania, Bulgaria and Greece experience the same difficulties [16]. The Polish case shows that in circumstances when natives are not willing to work in secondary and low remunerative sectors, immigrants (like Ukrainians arriving for seasonal short-term jobs in Poland) are regarded as complementary workforce. Though, the negative effects of complementary immigrant workforce may appear if these workers send major part of their salary to relatives residing in the country of origin [14].

To conclude, complementary immigrant workers bring more positive effects than negative. For example, they cover skills shortages and provide a host county with lacking workforce. High-skilled complementary immigrants create effective cooperation with local specialists, optimising industrial processes and boosting innovation. The only negative point here is a capital outflow, which takes place if family of the worker resides abroad.

Talking about effect of labour immigration on the welfare of local population, the US National Academies of Sciences on economic and fiscal consequences of immigration of 2017 argue that it depends on whether an immigrant comes to the host country with capital or not. In case immigrants arrive without capital and all existing capital is owned by locals, an influx of new immigrants makes each unit of the pre-existing capital stock more productive. Immigration raises the return to capital, in other words, it makes capital more productive and helps to increase income to owners of capital. So, the influx of immigrants pushes wages down, but aggregate income of natives rises due to immigration surplus. Consequently, natives who own more capital will receive more income from the immigration surplus than natives who own less capital, who can consequently be adversely affected. On the contrary, if immigrants arrive with considerable capital, so that capital of immigrants raises marginal product of labour, the wage and the rate of return to capital will not change at all. Although the economy will become larger, the immigrants' surplus will not exist. In this case, benefits of immigration will be paid as salaries to these immigrants, and income on imported capital also will contribute to increase of income of immigrants, who brought this capital. In other words, wages will remain stable, but there will not be an immigration surplus. Nevertheless, when production is characterised by high return to scale, capital imported by immigrants can help to increase wages and create positive immigration surplus [4, p. 167-168]. So, native population benefits much more in aggregated terms when immigrants come without capital, with an exception of economies of scale.

\section{Conclusions}

Immigration and its impact on local labour markets has been a highly discussed issue among researchers and policymakers. A variety of points of view on this issue circulate over policy debates. The EU was so much concerned of immigration workforce arriving into the European community that in 2016 the European Parliament adopted a resolution on the situation in the Mediterranean and the need for a holistic EU approach to migration, which in particular focuses on necessity to facilitate visa procedures to the 
third countries residents who can fill vacant positions in sectors experiencing workforce shortages.

Thousands of immigrants arrive to the EU every year. They endeavour to settle in the most advanced industrial economies, so Germany is a leading recipient of foreign labour force. Talking about immigrants, we usually refer to people who change their habitual residence for different reasons. In this report we discussed mostly economic immigration phenomenon. People who legally or illegally (or, regularly/irregularly) work abroad, influence greatly labour market of host country and participate in economic growth processes. We usually distinguish competing workers and complementing workers, depending on their propensity to substitute or, on the contrary, complement local workers. Further, we assess effects of immigrants labour on wages separately in the short and in the long run. We should admit, that in case of competing workers, effects on wages of locals is negative, though empirical studies, conducted in Germany, show that wages reduction is too tiny to be concerned of. In the long run, additional capital can be attracted to the manufacturing process, and wages grows, returning back to initial position.

In case of complementing immigrants' influx, the effects on wages are mostly positive, as these workers increase returns on capital and productivity, in particular boosting innovation (as for high-skilled immigrant workers) or filling labour market gaps. The negative effects of immigration consist in capital outflows when immigrant workers send share of their salary abroad, but this effect refers rather to current account balance than labour market.

Finally, immigrants' labour creates immigration surplus, which is an additional welfare that natives obtain due to labour of foreigners. This surplus is not equally distributed among natives: those who initially possessed more capital receives greater share of surplus. If immigrants arrive with considerable amount of capital, negative effect on wages is blurred, but immigration surplus disappears, as immigrant workers take their share of income, apart of wages. Moreover, capital imported by immigrants to the host country serves for enlargement of economy and creates benefits for economies of scale.

Protecting local labour market or, on the contrary, create incentives for immigrants' influx largely depends on a variety of factors, from structure of economy to prognosed skills shortages in the future. It should be decided individually by domestic policymakers, though, along to legal regulations developed by the EU at supranational level.

\section{References:}

1. Apap, J., Radjenovic, A. \& Dobreva, A., 2019. The migration issue, Brussels: EPRS.

2. Bansak, C., Simpson, N. B. \& Zavodny, M., 2015. The Economics of Immigration. 1st edition ed. s.1.:Routledge.

3. Beyer, R. C. M., 2016. The Labor Market Performance of Immigrants in Germany, s.l.: IMF.

4. Blau, F. D. \& Mackie, C., 2017. The Economic and Fiscal Consequences of Immigration, Washington, DC: The National Academies Press. 
5. Blinder, S. \& Anderson, B., 2019. Who Counts as a Migrant? Definitions and their Consequences, Oxford: COMPAS.

6. Burmann, M. et al., 2018. Highly Skilled Labour Migration in Europe, Munich: IFO.

7. Carbaugh, R., 2017. International Economics. 16th edition ed. s.1.:Cengage Learning.

8. Clemens, M. A., 2011. Economics and Emigration: Trillion-Dollar Bills on the Sidewalk?. Journal of Economic Perspectives, Summer, 25(3), pp. 83-106.

9. De Vito, E., Waure, C. d., Specchia, M. L. \& Ricciardi, W., 2015. Public health aspects of migrant health: a review of the evidence on health status for undocumented migrants in the European Region, Copenhagen: s.n.

10. Dumont, J.-C. \& Liebig, T., 2014. Is migration good for the economy?, s. 1: OECD.

11. European Parliament, 2016. Resolution of 12 April 2016 on the situation in the Mediterranean and the need for a holistic EU approach to migration, s. 1: s.n.

12. Eurostat, 2019. Migration and migrant population statistics. [Online]. Available at: https://ec.europa.eu/eurostat/statistics-explained/index.php/Migration_ and_migrant_population_statistics

13. Goldin, I., Pitt, A., Nabarro, B. \& Boyle, K., 2018. Migration and the Economy: Economic Realities, Social Impacts \& Political Choices, Oxford: Citi GPS: Global Perspectives \& Solutions.

14. Kindler, M., 2018. Poland's Perspective on the Intra-European Movement of Poles. Implications and Governance Responses. In: P. Scholten \& M. van Ostaijen, eds. Between Mobility and Migration: The Multi-Level Governance of Intra-European Movement. s. 1: Springer International Publishing, p. 270.

15. Lima, P. d. et al., 2016. Migration and the EU Challenges, opportunities, the role of EIB, Luxembourg: EIB.

16. ManpowerGroup, 2020. Skill Shortages in Poland. [Online]. Available at: https://www.worldwidecollege.in/country/Poland/Skill-Shortages-in-Poland

17.Mottu, E. \& Cangiano, M., 1998. Will Fiscal Policy Be Effective Under EMU?, s. 1: s.n.

18. OECD, 2019. International Migration Outlook 2019, Paris: OECD Publishing.

19. Strzelecki, P., Growiec, J. \& Wyszyński, R., 2020. The contribution of immigration from Ukraine to economic growth in Poland, Warsaw: NBP. Education \& Publishing Department.

20. Wolla, S. A., 2014. The Economics of Immigration: A Story of Substitutes and Complements. Page One Economics, May. 
Annex A

Table 1

Permanent immigrants' inflows as a share of population in the $\mathrm{EU}$ countries in 2007-2017,\%

\begin{tabular}{|l|c|c|c|c|c|c|c|c|c|c|c|}
\hline \multicolumn{1}{|c|}{ Country* } & $\mathbf{2 0 0 7}$ & $\mathbf{2 0 0 8}$ & $\mathbf{2 0 0 9}$ & $\mathbf{2 0 1 0}$ & $\mathbf{2 0 1 1}$ & $\mathbf{2 0 1 2}$ & $\mathbf{2 0 1 3}$ & $\mathbf{2 0 1 4}$ & $\mathbf{2 0 1 5}$ & $\mathbf{2 0 1 6}$ & $\mathbf{2 0 1 7}$ \\
\hline Luxembourg & 3.3 & 3.5 & 3 & 3.1 & 3.7 & 3.7 & 3.6 & 3.8 & 4 & 3.7 & 3.7 \\
\hline Ireland & 2.7 & 2 & 1.1 & 0.5 & 0.7 & 0.8 & 0.9 & 0.9 & 1.1 & 1.1 & 0.8 \\
\hline Spain & 2 & 1.2 & 0.8 & 0.7 & 0.7 & 0.6 & 0.5 & 0.6 & 0.6 & 0.8 & 0.7 \\
\hline Slovenia & 1.5 & 2.2 & 1.2 & 0.6 & 0.9 & 0.8 & 0.8 & 0.9 & 1 & 1 & 1.3 \\
\hline Austria & 1.1 & 1.1 & 1.1 & 1.2 & 1.3 & 1.5 & 1.6 & 1.8 & 2.3 & 1.8 & 1.1 \\
\hline Czech Republic & 1 & 0.7 & 0.4 & 0.3 & 0.2 & 0.3 & 0.3 & 0.4 & 0.3 & 0.3 & 0.4 \\
\hline Sweden & 0.9 & 0.9 & 0.9 & 0.8 & 0.8 & 0.9 & 1 & 1.1 & 1.2 & 1.5 & 1.3 \\
\hline Italy & 0.9 & 0.8 & 0.7 & 0.7 & 0.6 & 0.5 & 0.5 & 0.4 & 0.4 & 0.4 & 0.4 \\
\hline Belgium & 0.9 & 1 & 1 & 1 & 1.1 & 1.2 & 1.1 & 1 & 1.1 & 0.9 & 0.9 \\
\hline Germany & 0.7 & 0.7 & 0.8 & 0.8 & 1 & 1.2 & 1.4 & 1.7 & 2.5 & 2.1 & 1.1 \\
\hline Denmark & 0.6 & 0.7 & 0.6 & 0.6 & 0.6 & 0.6 & 0.7 & 0.9 & 1 & 1 & 1 \\
\hline Netherlands & 0.5 & 0.6 & 0.6 & 0.7 & 0.7 & 0.7 & 0.7 & 0.8 & 0.9 & 1.1 & 0.8 \\
\hline Greece & 0.4 & 0.4 & 0.4 & 0.3 & 0.3 & 0.3 & 0.3 & 0.3 & 0.3 & 0.3 & 0.7 \\
\hline France & 0.3 & 0.4 & 0.3 & 0.4 & 0.4 & 0.4 & 0.4 & 0.4 & 0.4 & 0.4 & 0.4 \\
\hline Finland & 0.3 & 0.4 & 0.3 & 0.3 & 0.4 & 0.4 & 0.4 & 0.4 & 0.4 & 0.5 & 0.4 \\
\hline Portugal & 0.3 & 0.7 & 0.6 & 0.5 & 0.4 & 0.4 & 0.3 & 0.3 & 0.4 & 0.5 & 0.4 \\
\hline Hungary & 0.2 & 0.4 & 0.3 & 0.2 & 0.2 & 0.2 & 0.2 & 0.3 & 0.3 & 0.2 & 0.4 \\
\hline Latvia & 0.2 & 0.2 & 0.1 & 0.1 & 0.1 & 0.2 & 0.2 & 0.2 & 0.2 & 0.2 & 0.2 \\
\hline Estonia & 0.2 & 0.1 & 0.2 & 0.1 & 0.1 & 0.1 & 0.1 & 0.1 & 0.6 & 0.6 & 0.7 \\
\hline Slovak Republic & 0.1 & 0.1 & 0.1 & 0.1 & 0.1 & 0.1 & 0.1 & 0 & 0.1 & 0.1 & 0.1 \\
\hline Poland & 0.1 & 0.1 & 0.1 & 0.1 & 0.1 & 0.1 & 0.1 & 0.1 & 0.2 & 0.3 & 0.3 \\
\hline Lithuania & 0.1 & 0.1 & 0.1 & 0 & 0.1 & 0.1 & 0.1 & 0.2 & 0.1 & 0.2 & 0.4 \\
\hline
\end{tabular}

Source: elaborated on the basis of OECD statistics

Data obtained from new-display.compareyourcountry.org in 2020-05-15

*Data on Croatia, Cyprus, Malta, and Romania is not available 